\title{
A study on Organizational Climate in Tamilnadu Cements in Ariyalur with special reference to Finance and Economic factors
}

\author{
${ }^{1}$ Dr.K.Neelameham, ${ }^{2}$ J.M.Velmurugan \\ ${ }^{1}$ Associate Professor in Business Administration Thanthai Hans Roever College Perambalur,Tamilnadu \\ ${ }^{2}$ Ph.D Research Scholar in Commerce and Lecturer in Commerce \& Management, Bharathidasan University \\ College, Perambalur,Tamilnadu
}

\begin{abstract}
The traditional values of getting a good job in a reputed organization being loyal to their staff, being loyal to their organization and of long term Company Staff with a single Company Staff are all going the way of the do-do bird. This is not a result of a degenerating of standards or social values; it is a response to a natural evolution in the market place. In the past we thought institution could be handled scientifically according to the Newtonian physics notions of cause and effect. Current trend say that institutions are best viewed as natural systems, which need to change in response to both the environment and the changing, makeup of the system involved.This is easy to say it is not easy to do. The vast majority of people still believe that a job-based society is the norm and science this is the only system they know their values reflect this belief. A Major task for corporations and governments over the next few decades will be one of moving people and their values into the more organically organized work place. Where jobs exist they will rarely have a standard job description or a fixed place in an institution chart. People will move within and among institution to the places they are needed and where their interests lie. When more people are needed, they will be brought into the system in any number of ways. When people are not needed, they will move out of the institution. The concept of job security of a thing will be the past.Everyone has experienced that how job services of librarian particularly in educational institution has eroded over the past few years. Hence the researcher is interested in studying how institutional climate ensure job security and build good morality among librarian in the work place Organization.

Keywords:Organizational Climate - Tancem - Perception - financial and Economic factors - Motivational factors such as savings, debt.
\end{abstract}

\section{Introduction}

Organizational climate is the perception of how if feels to work in a particular environment. It is "atmosphere of the workplace" including a complex combination of norms, values, expectations, policies and procedures that influence individual and group patterns of behavior. It is, in effect, people's perceptions of 'the way we do things here'. Each library system has its own personal policies, With the best limestone deposit a available it is able to product the high quality cement of various grades and supplies government departments and public. Wide application have been received from various quarters for its ARASU brand cement being marketed in Tamil Nadu and Kerala. Capacity enhancement at Ariyalur factory is also proposed of late it operates exceedingly well producing more than its capacity. Now TANCEM Ariyalur unit has installed ESPs at a total cost of Rs.3.00 crores for controlling the dust pollution as per the norms of Tamil Nadu pollution control board. The major plant and machinery are of physiques (West Germany) supplied by M/s. Walchandhagar Industries Ltd., pune. The plant is designed for adopting dry process technology with four stage suspension preheated DOPOL system and this was modern dry process plant in the continent of aria during 1979.

The cement produced in this plant is stacked in four cement sides and fed packing plant from where the same packed with help rotary packers. The is unit producing there kinds of cement as below:

ordinary Portland cement (OPC)

* Portland pozzalannna cement (PPC), and Clay.

\section{Statement of the Problem}

When men come together to do a job, they form an institution. Every human organization has its own pattern of inter-personal and task oriented relationship. In Company these relationships must be justified in economic terms. The job must be done, and a profit must be made. Organizational climate is the atmosphere created in organizations by the prevalent management style and the way in which top level authority and staff work together. The organizational climate can be described in terms of the amount and quality of team work and co-operation within the organization; the degree of commitment among the members of the organization. The effectiveness of communication; the extent to which planning and creativity are encouraged the way in which conflict or difference of opinion are resolved; the extent to which the employees participate in decision 
making; the extent to which the organizational relay upon mutual confidence and trust between managers and sup-ordinates rather than relaying on authority obedience relationship. Hence the researcher felt the need to know how the organization and motivation and productivity of individuals as well as the total work group. So main aim of the study was to analyze organization climate of the librarians in the college libraries. In order to carry out a study on organizational climate in Company especially company, the following are the aim main objectives and secondary of the present study.

\section{Objectives Of The Study:}

$>$ To study how the people have interpersonal relationship and trust with their superiors and how people trust and have confidence in each other.

$>$ To study the perception of company staff on management attitudes towards problem solving and how management involves subordinates in decision-making process.

$>$ To know the company staff opinion on salary benefits under reward system prevailing in the Company and its contribution to organization climate.

\section{Hypothesis}

$>$ There is no significant relation between type of family and overall organizational climate.

$>$ There is no significant relation with regard to religion and their overall perception of organizational climate.

$>$ There is no significant between nature of background and the overall perceptions of organizational climate.

\section{Research Design}

This study adopts the descriptive research design as it attempts to portray the respondents' opinions as they are. Descriptive research helps the researcher to describe accurately the characteristics of a phenomenon, an individual or an institution. Measures of central tendency like mean, measure of dispersing like range, minimum and maximum are used in the study.

\section{Sample Design}

This study does not employ the census method it is a sample based on simple random sampling where in the respondents fitting the criteria for the sample selection as listed under are selected randomly.

\section{Sample Size}

The simple random sampling was used for the Total number of respondent covered in the study is 150 To study the organization climate Company, a total of 150 samples which WORKERS 542 (Male 150) were selected for the study.

\section{Review Of Leterature}

The traditional values of getting a good job in a reputed organization being loyal to their staff, being loyal to their organization and of long term Company Staff with a single Company Staff are all going the way of the do-do bird. This is not a result of a degenerating of standards or social values; it is a response to a natural evolution in the market place. In the past we thought institution could be handled scientifically according to the Newtonian physics notions of cause and effect. Current trend say that institutions are best viewed as natural systems, which need to change in response to the environment and the changing, makeup of the system involved.

This is easy to say it is not easy to do. The vast majority of people still believe that a job-based society is the norm and science this is the only system they know their values reflect this belief. A Major task for corporations and governments over the next few decades will be one of moving people and their values into the more organically organized work place. Where jobs exist they will rarely have a standard job description or a fixed place in an institution chart. People will move within and among institution to the places they are needed and where their interests lie. When more people are needed, they will be brought into the system in any number of ways. When people are not needed, they will move out of the institution. The concept of job security of a thing will be the past.

Everyone has experienced that how job services of librarian particularly in educational institution has eroded over the past few years. Hence the researcher is interested in studying how institutional climate ensure job security and build good morality among librarian in the work place Organization.

\section{Organizational Climate}

Organizational climate is the perception of how if feels to work in a particular environment. It is "atmosphere of the workplace" including a complex combination of norms, values, expectations, policies and procedures that influence individual and group patterns of behavior. It is, in effect, people's perceptions of 'the 
way we do things here'. Each library system has its own personal policies, which differ widely from those of other library systems. Apart from the differences in policies, each library has its own unique. Just as the behavior of the individual can be differentiated on the basis of their personality, the companies also can be distinguished from one another by their unique climate.

\section{Concept of Organizational Climate}

Climate in natural sense is referred to as the average course or condition of the weather over a period of year as exhibited by temperature, wind velocity, and precipitation. Forehand and Glimer(1964) feel the 'climate consists of a set of characteristics that describe an organization, distinguishing it from other organizations are relatively enduring over time, influence and the behavior of people in it'. Organizational climate is also "A set of attributes specific to a particular organization that may be induced from way that organization deals with its members and its environment, for the individual members within the organization. Climate takes the form of a set of attitudes and expectance which describe in terms of both static characteristics (such as degree of autonomy) and behavior outcome and outcome-outcome contingencies" 2

When organizational climate is defined in this way many kinds of organizational factors are relevant contributors to it. The crucial elements are the individual's perceptions of the relevant stimuli, constraints, and reinforcement, contingencies that govern human behavior etc.

\section{Factors In Organizational Climate}

Litwin and stringer (1968) have included six factors, which affect organizational climate. These are (I) Organization structure-Perception of the extent of Organizational constraints, rules, regulations red-tape (II) Individual responsibility-feelings of autonomy of one's won boss (III) Rewards-feelings related to being confident of adequate and appropriate rewards. (IV) Risk and risk taking-perceptions of the degree of challenge and risk in the work situation. (V) Wrath and support-feelings of general good fellowship and helpfulness prevailing the work settings. (VI) Tolerance and conflict-degree of confidence that the climate can tolerate differing opinions ${ }^{3}$.

Schneider and Bartlett include six items that should be including in determined organizational climate. These are managerial support managerial structure, Concern for new library staffs; inter agency conflict, agent dependence, and general statisfaction ${ }^{4}$.

Taguiri (1958) has identified five factors in organizational climate on the basis of information provided by top authorities. These are

(I) Practices relating to providing a sense of direction or purpose to their jobs-setting of objectives planning and feedback.

(II) Opportunities for exercising individual initiative

(III) Working with a superior who is highly competitative and competent.

(IV) Working with co-operating and pleasant people.

(V) Being with a profit-minded and sale oriented Company.

Some board generalizations can be drawn and it can by conclude that four basic factors are somewhat common to the findings of most studies. There are individual autonomy, the degree of structure imposed upon the people, reward orientation, and consideration warmth and support ${ }^{5}$.

\section{Impact of Organizational Climate}

There is a mechanism by which organized climate affects performance, satisfaction, and attitudes of people in the organization.

$>$ Organizational sense by variable can operate as constraint system in both a positive and negative sense by providing knowledge of what kinds of behavior are rewarded, punished or ignored.

$>$ Organizational variable both physiological and psychological may affect behavior through evaluation of the self and others.

$>$ Organizational factors work as stimuli.

$>$ Organizational variables influence the individual to form a perception of the organization.

\section{Developing a Sound Organizational Climate:}

Organizational climate should represent the philosophy and goals of those who join together to create the organization. Thus the following features of a sound organizational climate are offered:

- Linking rewards with performance

- High standards of excellence

- Encouragement for participation and group decision

- Encouragement for innovation and freedom to act 
- High standard of moral, interpersonal amity and tolerance of individual difference

\section{Industrial Profile}

The cement industry is one of the main beneficiaries of the infrastructure boom. With robust demand and adequate supply, the industry has bright future. The Indian Cement Industry with total capacity of 165 million tones is the second largest after China. Cement industry is dominated by 20 companies who account for over $70 \%$ of the market. Individually no company accounts for over $12 \%$ of the market. The major players like L\&T and ACC have been quiet successful in narrowing the gap between demand and supply. Private housing sector is the major consumer of cement $(53 \%)$ followed by the government infrastructure sector. Similarly northern and southern region consume around 20\%-30\% cement while the central and western region are consuming only $18 \%-16 \%$.India is the 2 nd largest cement producer in world after china .Right from laying concrete bricks of economy to waving fly over's cement industry has shown and shows a great future. The overall outlook for the industry shows significant growth on the back of robust demand from housing construction, Phase-II of NHDP (National Highway Development Project) and other infrastructure development projects. Domestic demand for cement has been increasing at a fast pace in India. Cement consumption in India is forecasted to grow by over $22 \%$ by $2009-10$ from 2007-08.Among the states, Maharashtra has the highest share in consumption at $12.18 \%$,followed by Uttar Pradesh, In production terms, Andhra Pradesh is leading with $14.72 \%$ of total production followed by Rajasthan. Cement production grew at the rate of 9.1 per cent during 2006-07 over the previous fiscal's total production of 147.8 met (million tons). Due to rising demand of cement the sales volume of cement companies are also increasing \& companies reporting higher production, higher sales and higher profits. The net profit growth rate of cement firms was $85 \%$.Cement industry has contributed around $8 \%$ to the economic development of India. Outsiders (foreign players) eyeing India as a major market to invest in the form of either merger or FDI (Foreign Direct Investment). Cement industry has a long way to go as Indian economy is poised to grow because of being on verge of development. The company continues to emphasize on reduction of costs through enhanced productivity, reduction in energy costs and logistics expenses. The cement sector is expected to witness growth in line with the economic growth because of the strong co-relation with GDP. Future drivers of cement demand growth in India would be the road and housing projects. As per the Working Group report on Cement Industry for the formulation of the 11th Plan, the cement demand is likely to grow at 11.5 percent per annum during the 11th Plan and cement production and capacity by the end of the 11th Plan are estimated to be 269 million tones and 298 million tones

Despite the growth of Indian cement industry India lags behind the per capital production. Supply for cement is expected to remain tight which, in turn, will push up prices of cement by more than $50 \%$. The most important factor for better prices is consolidation of the industry. It has just begun and we will see more consolidation in the coming years. Other budget measures such as cut in import duty from 12.5 per cent to nil etc. are all intended to cut costs and boost availability of cement. Sadly the adverse effects of global slowdown have not speared this industry too. Demand is sluggish, the government is keeping an eagle eye on prizes, domestic coal and pet coke, prizes have increased sharply and utilizations rates are down. The numbers coming out are a reflection of grim times. ACC the country's largest cement company that's controlled by Swiss giant HOLCIM, registered $2 \%$ fall in august sales. It is the biggest fall since Feb 2007. Production fell by $5 \%$. To stand against the problematic situation, government as well as cement industry has taken some steps. Companies are focusing on cost of transportation. One of the strategy is to decrease dependence on road \& opt for sea logistics as that can cut transportation cost by 30-50\%. Some plants are adopting futuristic plan such asserting up captive power plant, moving closer to the customers by creating clicker, crushing, and capacity in key markets, to be more customer centric to generate better revenue. India should push for stricter regulations of market place as to control the prices of big companies and prevent them from forming cartels and exchanging information. To fight with the high inflation, government wants to import more cement from Pakistan .However cement prizes are not very much high as other items but still they are increasing. And the reason of high prize is surging cost of raw material and transportation cost. Apart from this government also discussed with cement industry not to have increase in prizes and keep consumer interest in mind. Now the question arise in front of the government is whether the demand by the government is possible to increase through expenditure on infrastructure or not according to the current state of economy when so many crises are going on or how the government allocation of US\$ 3.23 billion for the National Highway Development, Project will keep the demand for cement alive? And to what extent the prizes of cement should be increase so that consumer can't affect .Cement industry in India has also made tremendous strides in technological up gradation and assimilation of latest technology. Presently, 93 per cent of the total capacity in the industry is based on modern and environment-friendly dry process technology. The induction of advanced technology has helped the industry immensely to conserve energy and fuel and to save materials substantially. Indian cement industry has also acquired technical capability to produce different types of cement like Ordinary Portland Cement (OPC), Portland Pozzolana Cement (PPC),Portland Blast Furnace Slag Cement (PBFS), Oil Well Cement, Rapid 
Hardening Portland Cement, Sulphate Resisting Portland Cement, White Cement etc. Some of the major clusters of cement industry in India are: Satna (Madhya Pradesh),Chandrapur (Maharashtra), Gulbarga (Karnataka), Yerranguntla (Andhra Pradesh),Nalgonda (Andhra Pradesh), Bilaspur (Chattisgarh), and Chandoria (Rajasthan).

\section{Company Profile}

Now TANCEM Ariyalur unit has installed ESPs at a total cost of Rs.3.00 crores for controlling the dust pollution as per the norms of Tamil Nadu pollution control board. The major plant and machinery are of physiques (West Germany) supplied by M/s. Walchandhagar Industries Ltd., pune. The plant is designed for adopting dry process technology with four stage suspension preheated DOPOL system and this was modern dry process plant in the continent of aria during 1979. The cement produced in this plant is stacked in four cement sides and fed packing plant from where the same packed with help rotary packers. The is unit producing there kinds of cement as below:

* ordinary Portland cement (OPC)

* Portland pozzalannna cement (PPC), and Clay.

\section{COMPANY PROFILE}

Tamil Nadu cements corporation ( TANCEM ) a wholly a Government of Tamilnadu undertaking, business from $1^{\text {st }}$ April 1976 with an authorized share capital of Rs.10 cores taking over cement plant at alangulam and setting up another plant Ariyalur in 1979. Further all the shares were transferred to government of TamilNadu and now functioning under the control of industries department. The corporation is heated by chairman cum managing director, an IAS official.

\section{Categories of workers \\ * Workers level \\ * Skilled \\ * Unskilled \\ * Employees' level \\ Engineers \\ * Professionals and Number of employees}

In TANCEM seven hundred employees were working and their experiences of employees are almost twenty of twenty five years.

\section{Objectives of the TANCEM}

The company has its main objective in production of cement and cement based products and primarily cater to the needs government departments. Limestone being the main raw material, the company acquired and researched enough limestone bearing lands in and around alangulam and Ariyalur which are sufficient to run the cement plants for decoders to come hence the rle TANCEM in the development of state in immense. Besides the corporation has the objectives to provide employment opportunity to nearly 1000 members indirectly and 3000 members indirectly.

TANCEM is an inducement to provide industrial development in the most background are like Ariyalur, and sendurai regions. TANCEM, as its expansion and conversion activities set up asbestos sheet unit at alangulam during 1981 and an asbestos pressure pipe plant at mayanur during with a view to provide employment to the retrenched employees. TANCEM has thus become a multi plants, multi locations and multi Products Company with annul turnover of around Rs.200 cores and the authorized capital as of now is Rs. 18 cores.TANCEM'S Ariyalur unit was commissioned on $1^{\text {st }}$ Aug 1979 and commercial production in this unit was commenced during October 1979, set up with a capital outplay of Rs. 29 corers and a rated capacity of 5 laths tones per annul of cement. This Ariyalur unit is having two kilos of 750 TPD capacities each and producing Clinker of 1500 metric tones per day total. The cement brand name is Arasu.

\section{Objectives}

* Significant accounting polices

* System of accounting

Accounting are prepared under costing convention with revenue recognized and expense accounted on accrual provisions /adjustments for committed during the year as a going concern. Excise duty paid on removal of goods from factory and credit adjust mint of excise duty on account of input materials put on production are rotted through profit and loss account. This ccounting treatment has no impact on profits for the year. 


\section{Fixed assets and depreciation}

Fixed assets acquired are shown at the cost acquisition. In case of assets where subsidy has been received from the limestone dolomite welfare funds/the value has been reduced to the extent of subsidy received. Wherever credit on accountant of eligible CENVAT benefit of capital items are availed, the amount is deducted from the cost of fixed assets while capitalizing the same. . Depreciation is provided of fixed assets under straight line method at the rates prescribed in schedule XIV of the companies ACT 1956 as amended. Depreciation on quarry land has provided on the basis of depletion method. The fixed assets of the company are insured against fire risks for the acquisition Value/market value whichever applicable

\section{Inventories}

\begin{tabular}{|l|l|}
\hline Inventory & Basis of accounting \\
\hline Raw materials & $\begin{array}{l}\text { Annual average cost of production in respect of limestone } \\
\text { and weighted average cost for others less CENVAT } \\
\text { availed. }\end{array}$ \\
\hline Bonded material & CIF value, inland freight and custom duty \\
\hline $\begin{array}{l}\text { Stores, spares, consumables and } \\
\text { packaging materials }\end{array}$ & Weight average cost less CENVET availed \\
\hline Loose tools & Depreciated value \\
\hline Medicines and stationery & Annual average cost \\
\hline Process stock & At cost or net realizable value \\
\hline Finished goods & Lower of cost or net realized value \\
\hline
\end{tabular}

Finished products used for captive consumption within the same unit are accounted at cost those transferred to other units are accounted at cost and price and statutory levels. The value of scrap is taken at nil for accounting purposes. The entire amount realized is shown as miscellaneous receipt in the year of disposal.

\section{Development expenditure}

Development expenditure incurred at cement units for limestone mining and at stone factory for clay mining is being written off in the year in which the expense are incurred.

\section{Retirement benefits}

- Gratuity the liability is provided on the basis of actuarial valuation.

- In case of leave encashment the liability is provided on the basis of actuarial valuation.

- Lump-sum payment of the employees under the company voluntary retirement scheme is being written off over period of 36 months.

○ Bonus :

Liability for bonus is provided for the company as a whole treating all units of TANCEM as parts of same establishment for the purpose of computation of bonus as per the payment of bonus act, 1965 as amended.

\section{CEMENT}

With the best limestone deposit a available it is able to product the high quality cement of various grades and supplies government departments and public. Wide application have been received from various quarters for its ARASU brand cement being marketed in Tamil Nadu and Kerala.

Capacity enhancement at Ariyalur factory is also proposed of late it operates exceedingly well producing more than its capacity.Now TANCEM Ariyalur unit has installed ESPs at a total cost of Rs.3.00 crores for controlling the dust pollution as per the norms of Tamil Nadu pollution control board.

The major plant and machinery are of physiques (West Germany) supplied by M/s. Walchandhagar Industries Ltd., pune. The plant is designed for adopting dry process technology with four stage suspension preheated DOPOL system and this was modern dry process plant in the continent of aria during 1979.

The cement produced in this plant is stacked in four cement sides and fed packing plant from where the same packed with help rotary packers. The is unit producing there kinds of cement as below:

- $\quad$ ordinary Portland cement (OPC)

- Portland pozzalannna cement (PPC), and

- Clay.

The unit is classified by grade as below:

- O.P.C 43 and 53 grade

- P.P.C Arasu Super Star. 
Further the unit is having proposal to install electronics packer for meeting the dispatch program in a steam lined manner to maintain correct weight.

This chapter analysis about savings, debts, property, ownership, experience, power, relationship, organization, problems in Organisational climate let as discuss one by one.

TABLE - 1

DISTRIBUTION OF RESPONDENTS BY THEIR SUPPLEMENTARY INCOME

\begin{tabular}{|c|c|c|c|}
\hline S. No. & $\begin{array}{l}\text { Supplementary } \\
\text { Income }\end{array}$ & No. of Respondents & Percentage \\
\hline 1 & Yes & 36 & 24.0 \\
\hline 2 & No & 114 & 76.0 \\
\hline
\end{tabular}

Source :Primary data

It can be identified from the above table that $24 \%$ of respondent have additional inexplicable income from their sundry source but majority of them around $76 \%$ had no such supplementary income

TABLE - 2

DISTRIBUTION OF RESPONDENTS BY THEIR SAVINGS

\begin{tabular}{|c|c|l|c|}
\hline S. No. & Savings & No. of Respondents & Percentage \\
\hline 1 & Yes & 87 & 58.0 \\
\hline 2 & No & 63 & 42.0 \\
\hline
\end{tabular}

Source :Primary data

It can be inferred from the above table that $58 \%$ of the respondent have the capacity to have their surplus money in any one of the investment revenue where as $42 \%$ of them felt that the salary just sufficient to meet the domestic expenses.

TABLE - 3

DISTRIBUTION OF RESPONDENTS BY THEIR DEBTS

\begin{tabular}{|c|c|c|c|}
\hline S. No. & Debts & No. of Respondents & Percentage \\
\hline 1 & Yes & 48 & 32.0 \\
\hline 2 & $\mathrm{No}$ & 102 & 68.0 \\
\hline
\end{tabular}

Source :Primary data

It can be seen from the above table that only $32 \%$ of the respondent are burden with one loan or another where as $68 \%$ of them have never availed of any loan till now.

TABLE -4

DISTRIBUTION OF RESPONDENTS BY THEIR TYPE OF HOUSE

\begin{tabular}{|l|l|l|c|}
\hline S. No. & Type of House & No. of Respondents & Percentage \\
\hline 1 & Concrete & 132 & 88.0 \\
\hline 2 & Thatched & 18 & 12.0 \\
\hline
\end{tabular}

Source :Primary data

It could be known the above table that $88 \%$ of the respondents are living in the concrete house but $12 \%$ on the thatched house.

TABLE - 6

\section{DISTRIBUTION OF RESPONDENTS BY THEIR OWNERSHIP OF HOUSE}

\begin{tabular}{|c|l|l|c|}
\hline S. No. & $\begin{array}{l}\text { Ownership of } \\
\text { House }\end{array}$ & No. of Respondents & Percentage \\
\hline 1 & Own House & 99 & 66.0 \\
\hline 2 & Rented House & 51 & 34.0 \\
\hline
\end{tabular}

Source :Primary data

Majority of the respondent around $60 \%$ are having their own house where as $34 \%$ of them residing in the rented house. 
TABLE - 7

DISTRIBUTION OF RESPONDENTS BY THEIR YEARS OF EXPERIENCE

$\left.\begin{array}{|c|l|l|c|}\hline \text { S. No. } & \text { Years of Experience } & \text { No. of Respondents } & \text { Percentage } \\ \hline 1 & \text { Up to 15 years } & 78 & 52.0 \\ \hline 2 & 15-18 \text { years } & 42 & 28.0 \\ \hline 3 & 18-20 \text { years } & 15 & 15\end{array}\right]$

Source :Primary data

From the above table it is clear that majority of the respondents (52\%) have less than 5 years of experience in the company field and 28 of the respondents have 6 to 10 years of experience. But only $20 \%$ of the respondents have more than 11 years of services.

TABLE -8

DISTRIBUTION OF RESPONDENTS BY THEIR AUTONOMY TO

FUNCTION

\begin{tabular}{|c|l|l|c|}
\hline S. No. & Autonomy to Function & No. of Respondents & Percentage \\
\hline 1 & Yes & 105 & 70.0 \\
\hline 2 & No & 45 & 30.0 \\
\hline
\end{tabular}

Source :Primary data

It can be seen from the table that about $70 \%$ of the companion are independently working and feel from the head of the institution. Where as $30 \%$ of them had worried above unwanted comments and undue influence in the library work

TABLE - 9

DISTRIBUTION OF RESPONDENTS BY THEIR RELATIONSHIP WITH COMPANY

\begin{tabular}{|c|l|l|c|}
\hline S. No. & Relationship With college & No. of Respondents & Percentage \\
\hline 1 & Good & 108 & 72.0 \\
\hline 2 & Satisfactory & 42 & 28.0 \\
\hline
\end{tabular}

Source :Primary data

It is seen from the above that nearly $72 \%$ of the respondent had long term binding and loyalty with college management where as $28 \%$ of them felt that the relationship between library and college management are satisfactory.

TABLE - 10

DISTRIBUTION OF RESPONDENTS BY THEIR OBJECTIVE OF ORGANISATION

\begin{tabular}{|c|l|l|c|}
\hline S. No. & $\begin{array}{l}\text { Objective } \\
\text { Company }\end{array}$ & of & $\begin{array}{l}\text { Percentag } \\
\text { ef Respondents }\end{array}$ \\
\hline 1 & Helping People & 126 & 84.0 \\
\hline 2 & Profit & 18 & 12.0 \\
\hline 3 & Publicity & 3 & 2.0 \\
\hline 4 & Others & 3 & 2.0 \\
\hline
\end{tabular}

Source :Primary data

Majority of the respondent above $84 \%$ expressed that motto of the college in helping the people for their studies and would their career. But only $12 \%$ of them said that the college conduct the various courses only for securing the profit.

TABLE - 11

DISTRIBUTION OF RESPONDENTS BY SENT FOR SPECIAL TRAINING

\begin{tabular}{|c|c|l|c|}
\hline S. No. & Sent for Special Training & No. of Respondents & Percentage \\
\hline 1 & Yes & 63 & 42.0 \\
\hline 2 & No & 87 & 58.0 \\
\hline
\end{tabular}


Source :Primary data

It can be known from the above table that $24 \%$ of the respondent were encouraged to participate to special training program. Where as 58\% of them are not permitted to attend any training programs offered by university or any other institution.

TABLE -12

DISTRIBUTION OF RESPONDENTS BY SUPPORTED TO DO HIGHER STUDIES

\begin{tabular}{|c|l|l|l|}
\hline S. No. & $\begin{array}{c}\text { Supported to do } \\
\text { Higher studies }\end{array}$ & No. of Respondents & Percentage \\
\hline 1 & Yes & 114 & 76.0 \\
\hline 2 & No & 36 & 24.0 \\
\hline
\end{tabular}

Source :Primary data

It can be understanding from there above table that majority of the respondent about $76 \%$ were supported by the college management to do higher studies where $24 \%$ of them have had better experience while getting permission to study further through.

TABLE - 13

DISTRIBUTION OF RESPONDENTS BY THEIR MATERIAL PROBLEMS

\begin{tabular}{|c|c|l|c|}
\hline S. No. & Material Problems & $\begin{array}{l}\text { No. of Respondents } \\
(\mathbf{n : 1 5 0 )}\end{array}$ & Percentage \\
\hline 1 & Yes & 24 & 16.0 \\
\hline 2 & No & 126 & 84.0 \\
\hline
\end{tabular}

Source :Primary data

The above table revealed that majority of the respondent had not faced any material problem but only $16 \%$ of them said very bad about material problem.

TABLE - 14

DISTRIBUTION OF RESPONDENTS BY WISH TO CONTINUE THE SAME FIELD

\begin{tabular}{|c|c|c|c|}
\hline S. No. & $\begin{array}{c}\text { Continue The same } \\
\text { field }\end{array}$ & No. of Respondents & Percentage \\
\hline 1 & Yes & 129 & 86.0 \\
\hline 2 & No & 21 & 14.0 \\
\hline
\end{tabular}

Source :Primary data

It can be identified that the respondents (8\%) are wishing to continue in the same field. But remaining $14 \%$ of the respondents are not satisfied in their field.

TABLE -1

DISTRIBUTION OF RESPONDENTS BY VARIOUS DIMENSIONS OF ORGANIZATIONS

CLIMATE

\begin{tabular}{|l|l|l|l|l|}
\hline \multirow{2}{*}{ Sl. No. } & \multicolumn{2}{|l|}{$\begin{array}{l}\text { Various Dimensions Of Organizations } \\
\text { Climate }\end{array}$} & $\begin{array}{l}\text { No. } \\
\text { Respondents } \\
(\mathbf{n}: 150)\end{array}$ & Percentage \\
\hline \multirow{2}{*}{1} & \multirow{2}{*}{ Communication } & Low & 45 & 30.0 \\
\cline { 3 - 5 } & & High & 105 & 70.0 \\
\hline \multirow{2}{*}{2} & Low & 57 & 38.0 \\
\cline { 3 - 5 } & Role & High & 93 & 62.0 \\
\hline \multirow{2}{*}{3} & \multirow{2}{*}{ Structure } & High & 48 & 32.0 \\
\hline \multirow{2}{*}{4} & \multirow{2}{*}{ Responsibility } & Low & 102 & 68.0 \\
\cline { 3 - 5 } & \multirow{2}{*}{5} & High & 54 & 36.0 \\
\hline \multirow{2}{*}{6} & Low & 96 & 64.0 \\
\cline { 3 - 5 } & \multirow{2}{*}{ Overald } & High & 75 & 50.0 \\
\cline { 3 - 5 } & Low & 75 & 50.0 \\
\hline
\end{tabular}

Source :Primary data 
From the above table it is observed that regard to communication of the respondents $30 \%$ had low perception towards organizational climate and $70 \%$ had high perception towards organizational climate.

With regard to role $38 \%$ of the respondents had low perception towards organizational climate and $62 \%$ had high perception towards organization climate.

With regard to structure $32 \%$ of the respondent had low perception towards organizational climate and $68 \%$ of them high perception towards organization climate.

With regard to responsibility $36 \%$ of the respondent had low perception towards organizational climate and $64 \%$ of the respondent of them had high (formal) perception towards organizational climate.

With regard to reward to $50 \%$ of the respondent had low perception towards organizational climate and $50 \%$ of them had high perception towards organizational climate.

Regarding the overall organization climate score of the libraries it was found that exactly $46 \%$ of the respondents had to low perception of organizational climate and 54\% of the respondents had high perception of organizational climate.

TABLE -2

' $T$ ' TEST BETWEEN THE RESPONDENTS RELIGION WITH REGARD TO VARIOUS DIMENSIONS OF ORGANIZATIONS CLIMATE

\begin{tabular}{|c|c|c|c|c|}
\hline S. No. & Sex & $\mathrm{X}$ & S.D. & Statistical Inference \\
\hline \multirow[t]{3}{*}{1} & Communication & & & $t=0.705$ \\
\hline & Hindu & 12.16 & 2.26 & $\mathrm{p}>0.05$ \\
\hline & Christian & 11.71 & 2.20 & Not Significant \\
\hline \multirow[t]{3}{*}{2} & Role & & & $t=1.726$ \\
\hline & Hindu & 15.23 & 3.16 & $\mathrm{p}>0.05$ \\
\hline & Christian & 13.57 & 3.37 & Not Significant \\
\hline \multirow[t]{3}{*}{3} & Structure & & & $\mathrm{t}=0.846$ \\
\hline & Hindu & 11.40 & 2.00 & $\mathrm{p}>0.05$ \\
\hline & Christian & 11.86 & 1.88 & Not Significant \\
\hline \multirow[t]{2}{*}{4} & $\begin{array}{l}\text { Responsibility } \\
\text { Hindu }\end{array}$ & 1298 & 187 & $\begin{array}{l}\mathrm{t}=1.145 \\
\mathrm{n}>0.05\end{array}$ \\
\hline & Christian & 12.29 & 2.13 & Not Significant \\
\hline \multirow[t]{3}{*}{5} & Rewards & & & $\mathrm{t}=0.177$ \\
\hline & Hindu & 12.00 & 2.45 & $\mathrm{p}>0.05$ \\
\hline & Christian & 11.86 & 2.68 & Not Significant \\
\hline \multirow[t]{2}{*}{6} & Overall & & & $\mathrm{t}=1.529$ \\
\hline & Hindu & 73.76 & 5.86 & $\mathrm{p}>0.05$ \\
\hline 7 & Christian & 61.28 & 5.59 & Not Significant \\
\hline
\end{tabular}

Source :Primary data
It is referred that there is no significant relation with regard to religion and their overall perception of organization climate.

TABLE -3

'T' TEST BETWEEN THE RESPONDENTS TYPE OF FAMILY WITH REGARD TO VARIOUS DIMENSIONS OF ORGANIZATIONS CLIMATE

\begin{tabular}{|c|c|c|c|c|}
\hline S. No. & Sex & $\mathrm{X}$ & S.D. & Statistical Inference \\
\hline \multirow[t]{3}{*}{1} & Communication & & & $\mathrm{t}=0.903$ \\
\hline & Nuclear Family & 11.93 & 2.38 & $\mathrm{p}>0.05$ \\
\hline & Joint Family & 12.33 & 2.06 & Not Significant \\
\hline \multirow[t]{3}{*}{2} & Role & & & $\mathrm{t}=1.737$ \\
\hline & Nuclear Family & 14.55 & 3.58 & $p>0.05$ \\
\hline & Joint Family & 15.62 & 2.57 & Not Significant \\
\hline \multirow[t]{3}{*}{3} & Structure & & & $\mathrm{t}=1.959$ \\
\hline & Nuclear Family & 11.14 & 2.01 & $\mathrm{p}>0.05$ \\
\hline & Joint Family & 11.90 & 1.87 & Not Significant \\
\hline \multirow[t]{3}{*}{4} & Responsibility & & & $t=1.669$ \\
\hline & Nuclear Family & 12.62 & 2.08 & $p>0.05$ \\
\hline & Joint Family & 13.24 & 1.67 & Not Significant \\
\hline \multirow[t]{3}{*}{5} & Rewards & 12.00 & 3.32 & $\mathrm{t}=0.070$ \\
\hline & Nuclear Family & 11.95 & 3.41 & $\mathrm{p}>0.05$ \\
\hline & Joint Family & & & Not Significant \\
\hline \multirow[t]{3}{*}{6} & Overall & 62.241 & 5.161 & $\mathrm{t}=2.334$ \\
\hline & Nuclear Family & 65.047 & 6.435 & $p>0.05$ \\
\hline & Joint Family & & & Not Significant \\
\hline
\end{tabular}


Source :Primary data

It is found that there is significant relation between the respondents type of family i.e. nuclear family and joint family with the overall perception of organizational climate.

TABLE - 4

KARL PEARSON'S CO-EFFICIENT OF CORRELATION BETWEEN THE RESPONDENTS FAMILY MEMBERS AND VARIOUS DIMENSIONS OF ORGANIZATIONS CLIMATE

\begin{tabular}{|c|l|c|r|}
\hline S.NO & Variable & $\begin{array}{c}\text { Correlation } \\
\text { Value }\end{array}$ & Statistical Inference \\
\hline 1. & $\begin{array}{l}\text { Family } \\
\text { member\&Communication }\end{array}$ & -0.002 & $\mathrm{p}>0.05$ Not Significant \\
\hline 2. & Family member\&Role & -0.296 & $\mathrm{P}<0.01 \quad$ Significant \\
\hline 3. & Family member\& Structure & -0.123 & $\mathrm{P}<0.05$ Significant \\
\hline 4. & $\begin{array}{l}\text { Family } \\
\text { member\&Responsibility }\end{array}$ & -0.037 & $\mathrm{p}>0.05$ Not Significant \\
\hline 5. & Family Size andRewards & -0.096 & $\mathrm{p}>0.05$ Not Significant \\
\hline 6. & Family Size and Overall & -0.272 & $\mathrm{p}>0.05$ Not Significant \\
\hline
\end{tabular}

Source :Primary data

It is referred that there is no significance relationship between the respondents family size with their overall perception of organizational climate

\section{FINDINGS}

$58 \%$ having personal savings and $42 \%$ having no personnel savings.

$>68 \%$ having no debts and $32 \%$ having debts.

$>88 \%$ line in concrete buildings and $12 \%$ is thatched roof.

$>34 \%$ line in rented hours and $66 \%$ live in own house.

$>70 \%$ of the respondent has autonomy to function in companies and $30 \%$ do not having autonomy to function in companies.

$>72 \%$ of the respondents' relationship is good and $28 \%$ of them say it is satisfactory.

$>84 \%$ of the respondents feel that the management objective is to help the public $16 \%$ feel it is for profit and publicity.

$>42 \%$ of the respondents have undergone - special training through the management and $58 \%$ has not undergone any training.

$>76 \%$ of the respondents have been supported by the management to go for higher studies and $24 \%$ have not got the support of the management to go for higher studies.

$>86 \%$ of them wish to continue in the same field and $14 \%$ of them do not wish to continue in the same field.

\section{SUGGESTIONS}

* There is no significant relationship between autonomy to work and their overall perception of organization climate. Hence, the hypothesis is accepted.

* There is no significant relation between the respondents age with their overall perception organization climate. Hence, the proposed hypothesis is rejected.

* There is significant relation between the respondents age with their overall perception organization climate. Hence, the proposed hypothesis is rejected.

* There is no significant relation between respondent's yearly income and various perception of overall organization climate. Hence, the proposed hypothesis is accepted.

* There is no significant relation between respondents year of experience with their overall perception of organization climate. Hence the proposed hypothesis is accepted.

* There is no significant relation between respondents of family with their overall perception of organization climate.

There is significant relation between respondents family income with their overall perception of organization climate. Hence proposed hypothesis is access 


\section{Conclusion}

It is concluded that in the view of positive relationship between equity and employee performance, top management in the institution should recognize the need to reward the employees with adequate monetary compensation allow them to participate in the management affairs, create terms sprit and group behavior with constitute the organizational climate. How ever it is found from the present study that the company staff are felt very happy with present pleasant organizational environment in the educational institute special reference with companions.

\section{Bibliography}

[1] DAVIS.K, Human Behavior at Work, Tata McGraw, New Delhi, 1975

[2] AGRWAL. R D, Dynamics of personnel management in India, Tata MC Graw Hill, New Delhi, 2000.

[3] DAVAR Rs, The Human side of management progressive Corporation Private Limited. Bombay, 1998.

[4] DWIVEDI.R.S “ Human side of management Progressive Corporation Private Limited, 2000.

[5] FRED LUTTHANS, Organizational Behavior, Tata Mc Graw Hill New Delhi. $4^{\text {th }}$ Edition, 2002

[6] MEMORIA. C.B, Personnel Management, Himalaya Publishing House Bombay, 2000.

[7] PETER F DRUCKER, Managing for results, Allied Publishers, Bombay, 2001 